\title{
A Study on Energy Optimization of Heat Exchangers in a Gasification System
}

\author{
Le Minh Nhut ${ }^{1}$, Young-Sub Moon ${ }^{2}$, Youn Cheol Park ${ }^{3, *}$ \\ ${ }^{1}$ Department of Thermal Engineering, Faculty of Vehicle and Energy Engineering, Ho Chi Minh City University of Technology and Education, \\ Ho Chi Minh City, Vietnam \\ ${ }^{2}$ Research and Development Center, POSCO E\&C, Incheon City, Republic of Korea \\ ${ }^{3}$ Department of Thermal Engineering, Faculty Mechanical Engineering, Jeju National University, Jeju, Republic of Korea
}

\section{Email address:}

nhutlm@hcmute.edu.vn (Le M. N.), ysmoon@poscoenc.com (Young-Sub M.), ycpark@jejunu.ac.kr (Youn C. P.)

${ }^{*}$ Corresponding author

\section{To cite this article:}

Le Minh Nhut, Young-Sub Moon, Youn Cheol Park. A Study on Energy Optimization of Heat Exchangers in a Gasification System. International Journal of Mechanical Engineering and Applications. Vol. 4, No. 3, 2016, pp. 123-129. doi: 10.11648/j.ijmea.20160403.14

Received: May 16, 2016; Accepted: May 27, 2016; Published: June 13, 2016

\begin{abstract}
The objective of this research is the optimization of energy parameters such as the temperature and flow rate of the fluid in heat exchangers in the gasification system in order to increase the recovery rate of energy in the system. A mathematical model of these heat exchangers is developed to predict their operating performance under the specified gasification system. The optimal flow rate and temperature of the fluid in the heat exchanger based on the effectiveness - number of transfer units(NTU) method is investigated. The result of the simulation shows that the optimal mass flow rate and temperature of the high pressure (HP) boiler feed water are determined at $175,907 \mathrm{~kg} / \mathrm{h}$ and $110^{\circ} \mathrm{C}$, respectively, while the optimal mass flow rate and temperature of high pressure saturated steam of boiler are determined at $238,430 \mathrm{~kg} / \mathrm{h}, 290.5^{\circ} \mathrm{C}$, respectively. At these values, the total heat amount obtained at these heat exchangers is highest with $169 \mathrm{MW}$. Besides, the total heat amount obtained at heat exchangers could be increased by $4.61 \%(7.8 \mathrm{MW})$ when sixty percent of the heat release amount from air cooler (12.78 MW) is used.
\end{abstract}

Keywords: Optimization, Heat Exchanger, Gasification System, Effectiveness-NTU

\section{Introduction}

The demand for natural gas due to the increased population and economic growth of the world's population has caused the depletion of natural gas resources, as well as price increments, in recent years. It is necessary to discover alternative ways to develop a substitute for natural gas resources. Natural gas obtained from the coal gasification process is counted as a substitute resource to satisfy the growing demands of power generation and home utilization in the near future. Synthesized natural gas (SNG) has many advantages. It can be produced from inexpensive carbonaceous feedstocks and the removal of contaminants such as sulphur from coal makes coal gasification a more environmentally friendly means of energy conversion compared to the normal combustion of solid coal. Also, it has a high conversion efficiency, is easy, and it is cost effective to remove carbon dioxide by the separation of highly concentrated $\mathrm{CO}_{2}$ - stream, as inherent to all SNGprocesses [1-3]. The gasification process of a pressurized, oxygen-blown, entrained-flow E-Gas like gasifier through numerical modeling is investigated by solving the $3-\mathrm{D}$, steady-state Navier-Stokes equations with the EulerianLagrangian method [4]. The study indicates that the increasing $\mathrm{O}_{2} /$ Coal ratio results in a decrease of $\mathrm{CO}$, but an increase of $\mathrm{CO}_{2}$ and exit temperature. Jaojaruek [5] presented a study to predict the temperature profile, feedstock consumption rate (FCR) and reaction equivalence ratio (RER). A mathematical model for the entire length of a downdraft gasifier is proposed using thermochemical principles to derive energy and mass conversion equations. The analysis results show that model-predicted temperature fitted well with experimental data especially on the pyrolysis zone. Combustion and gasification zones had maximum temperature error of $52^{\circ} \mathrm{C}$ or $7.8 \%$.

In this study, a simulation program is developed, based on the mathematical model of the waste heat recovery heat 
exchangers to predict their operating performance and to obtain optimal information of the temperature and flow rate of the fluid in the heat exchangers of the gasification process.

\section{Mathematical Model of Heat Exchanger}

Gasification is a proven manufacturing process that converts hydrocarbons such as coal, petroleum coke, and biomass to a synthesis gas (syngas). In the coal gasification process of converting coal to $\mathrm{SNG}$, coal is gasified with steam and oxygen. The gasification process produces carbon monoxide $(\mathrm{CO})$, hydrogen $\left(\mathrm{H}_{2}\right)$, carbon dioxide $\left(\mathrm{CO}_{2}\right)$, methane $\left(\mathrm{CH}_{4}\right)$, and higher hydrocarbons such as ethane and propane [5]. Methanation reaction is the main process of converting coal to gas. In the methanation reactors $\mathrm{CO}, \mathrm{CO}_{2}$, and $\mathrm{H}_{2}$ are converted into $\mathrm{CH}_{4}$ according to the following reactions:

$$
\begin{aligned}
& \mathrm{CO}+3 \mathrm{H}_{2} \Leftrightarrow \mathrm{CH}_{4}+\mathrm{H}_{2} \mathrm{O}+\text { heat } \\
& \mathrm{CO}_{2}+4 \mathrm{H}_{2} \Leftrightarrow \mathrm{CH}_{4}+2 \mathrm{H}_{2} \mathrm{O}+\text { heat }
\end{aligned}
$$

Parallel with these methanation reactions, the water gas shift reaction will arouse to make equilibrium in all methanators:

$$
\mathrm{CO}+\mathrm{H}_{2} \mathrm{O} \Leftrightarrow \mathrm{CO}_{2}+\mathrm{H}_{2}+\text { heat }
$$

Methanation reactions in equations (1) and (2) are highly exothermic. In order to recover the waste heat from these reactions, heat exchangers need to be installed between each methanator to improve system performance and in order to utilize the highly pressurized superheated steam for power generation with a steam turbine.

The heat exchanger used in this gasification system for the waste heat recovery is the counterflow heat exchanger, while the effectiveness - number of transfer units (NTU) method is used for the analysis. The exchanger heat transfer effectiveness is determined by Sadik Kakac [20]:

$$
\varepsilon=\frac{Q}{Q_{\max }}
$$

This is the ratio of the actual heat transfer rate $\mathrm{Q}$ in a heat exchanger to the thermodynamically limited maximum possible heat transfer rate $Q_{\max }$ if an infinite heat transfer area were available in a counterflow heat exchanger. The value of $\varepsilon$ ranges between 0 and 1 and the actual heat transfer is calculated by:

$$
Q=\left(\dot{m} c_{p}\right)_{h}\left(T_{h 1}-T_{h 2}\right)=\left(\dot{m} c_{p}\right)_{c}\left(T_{c 2}-T_{c 1}\right)
$$

where $\left(\dot{m} c_{p}\right)_{h}$ and $\left(\dot{m} c_{p}\right)_{c}$ are the capacity rate of the hot fluid and the cold fluid, respectively. $T_{h 1}$ and $T_{h 2}$ are the inlet temperature and the outlet temperature of the hot fluid and $T_{c 1}$ and $T_{c 2}$ are the inlet temperature and the outlet temperature of the cold fluid, respectively.

The maximum possible heat transfer is expressed as:

$$
Q_{\max }=\left(\dot{m} c_{p}\right)_{c}\left(T_{h 1}-T_{c 1}\right)
$$

if

$$
C_{c}=\left(\dot{m} c_{p}\right)<C_{h}=\left(\dot{m} c_{p}\right)_{h}
$$

and

$$
Q_{\max }=\left(\dot{m} c_{p}\right)_{h}\left(T_{h 1}-T_{c 1}\right)
$$

if

$$
C_{h}=\left(\dot{m} c_{p}\right)<C_{c}=\left(\dot{m} c_{p}\right)_{c}
$$

The heat transfer area number is given by Sadik Kakac [9]:

$$
N T U=\frac{A U}{C_{\min }}
$$

where $\mathrm{U}$ and $\mathrm{A}$ are the overall heat transfer coefficient and the heat transfer surface area between the hot fluid and the cold fluid, respectively, and $C_{\min }$ is the smaller of $C_{h}$ and $C_{c}$.

Eq. (4) may be re-written using Eqs. $(5,6),(7),(8)$, and (9) as follows:

$$
\varepsilon=\frac{1-\exp \left[-N T U\left(1-C_{\min } / C_{\max }\right)\right]}{1-\left(C_{\min } / C_{\max }\right) \exp \left[-N T U\left(1-C_{\min } / C_{\max }\right)\right]}
$$

In this study, the total inlet energy of the heat exchangers of the gasification system was calculated as follows:

$$
H_{i}=H_{i H P B F W}+H_{i H P S T B}
$$

where $H_{i H P B F W}, H_{i H P S T B}$ are the inlet energy of the high pressure boiler feed water (HPBFW) and the inlet energy of the high pressure saturated steam of the boiler (HPSTB), respectively.

The total outlet energy of the heat exchangers of the gasification system was given by Eq. (11):

$$
H_{o}=H_{o H P S S T}+H_{o F P R E}+H_{o L P C D}
$$

where $H_{\text {OHPSST }}, H_{\text {OFPRE }}$ and $H_{\text {OLPCD }}$ are the outlet energy of the high pressure superheated steam to turbine (HPSST) and the outlet energy of the feed preheater (FPRE), and the outlet energy of the low pressure condensate drum (LPCD), respectively.

The total recovery energy of the heat exchangers was given as Eq. (12)

$$
\delta H=H_{o}-H_{i}
$$


From the mathematical model of heat exchanger based on the effectiveness-NTU method, an EES (Engineering Equation Solver) program is written to simulate the optimal mass flow rate and temperature of the fluid in the heat exchangers of the gasification system.

\section{System Description}

The schematic diagram of the steam production by waste heat recovery from methanation reactions of the gasification system is presented in Fig. 1. Normally, the main process in the methanation unit include gas cleaning, bulk methanation, trim methanation, catalytic oxidation, and drying processes. However, this investigation is focused only on the main heat exchangers and methanators because the gasification system has too many devices with complexities.

The designed methanation process has production capacity with 500,000 metric tons per year based on feedstock from a coal gasification unit. During the methanation process, the plant also generates highly pressurized superheated steam at $70 \mathrm{bar}, 490^{\circ} \mathrm{C}$ from the waste heat recovery of methanation reactions for steam turbine uses.

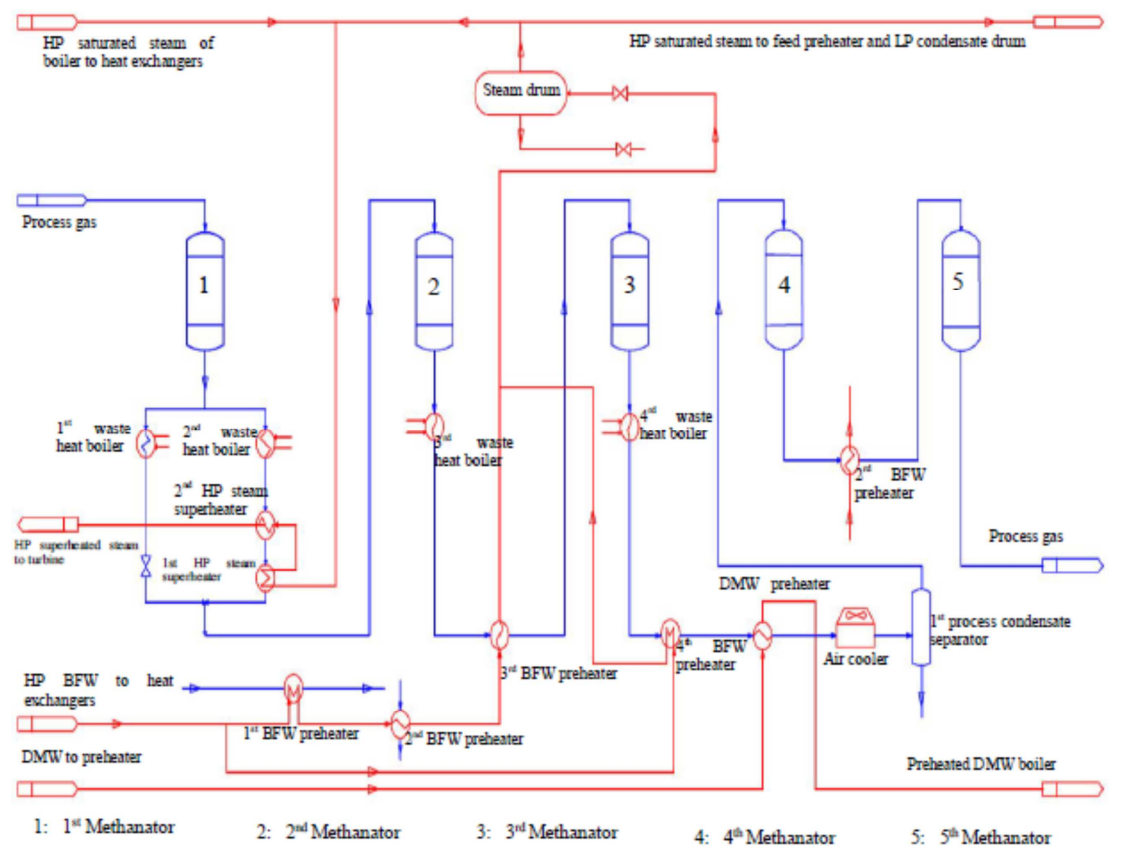

Fig. 1. Schematic diagram of the steam production by waste heat recovery of the gasification system.In the methanator, $\mathrm{CO}_{\text {, }} \mathrm{CO}_{2}$, and $\mathrm{H}_{2}$ are converted into $\mathrm{CH}_{4}$ that is highly exothermic. In order to optimize the conversion of $\mathrm{CO}, \mathrm{CO}_{2}$, and $\mathrm{H}_{2}$ to $\mathrm{CH}_{4}$ and to utilize the amount of heat of the reaction, the process is divided into a series of adiabatic methanators with interstage cooling, as illustrated in Fig. 1.

After the 1st methanator, the process gas is cooled down at the downstream waste heat recovery section by the 1 st waste heat boiler and the 2 nd waste heat boiler. The 2 nd waste heat boiler is followed by two super heaters, the 1st HP steam superheater and 2nd HP steam superheater, and the temperature of the process gas is reduced from $675^{\circ} \mathrm{C}$ to $320^{\circ} \mathrm{C}$.

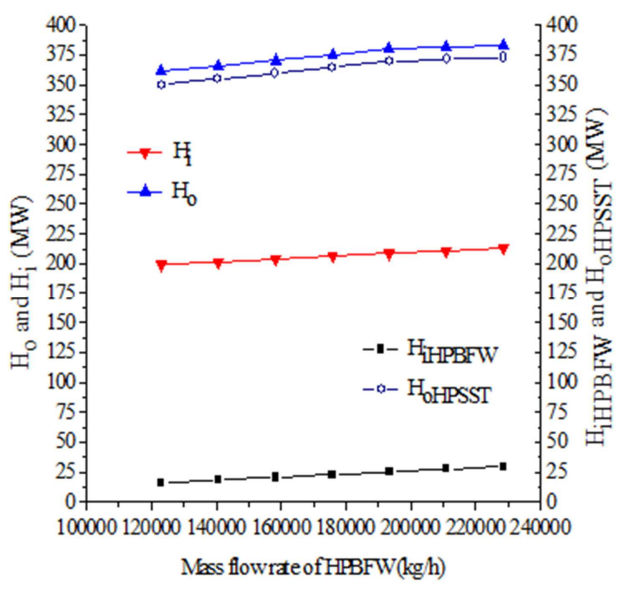

(a) Effect of the total inlet energy (Hi)

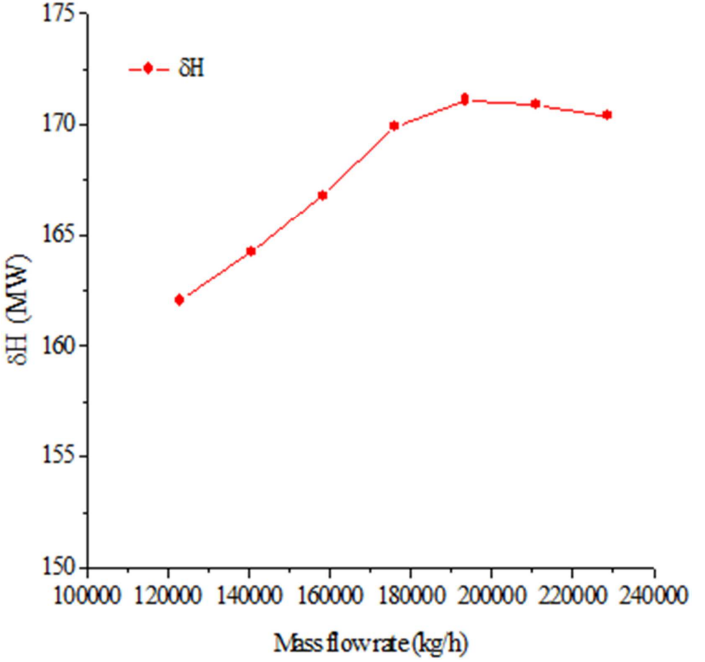

(b) Effect of the total recovery energy $\delta H$

Fig. 2. Effect of the inlet mass flow rate of the high pressure boiler feed water on the total inlet energy, the total outlet energy and the total recovery energy.

The total outlet energy $\left(\mathrm{H}_{\mathrm{o}}\right)$; The inlet energy of the HPBFW $\left(\mathrm{H}_{\mathrm{iHPBFW}}\right)$ and the outlet energy of the HPSST $\left(\mathrm{H}_{\mathrm{oHPSST}}\right)$ 
The major part of the conversion of $\mathrm{CO}, \mathrm{CO}_{2}$, is completed in the two subsequent methanators: the $2^{\text {nd }}$ methanator and the $3^{\text {rd }}$ methanator. The $2^{\text {nd }}$ methanator operates at a high temperature while the $3^{\text {rd }}$ methanator operates at a lower temperature. After the $2^{\text {nd }}$ methanator, the process gas is cooled by the $3^{\text {rd }}$ methanator's waste heat boiler and the $3^{\text {rd }}$ methanator's boiler feed water (BFW) pre-heater. While after $3^{\text {rd }}$ methanator the process gas is cooled by $4^{\text {th }}$ the waste heat boiler that is followed by a series of heat exchangers, where the heat is utilized to preheat boiler feed water and demineralised water in the $4^{\text {th }}$ BFW Preheater, and DMW Preheater, respectively. The process gas is finally cooled in an Air Cooler. After cooling the process gas, the process condensate is separated in the $1^{\text {st }}$ Process Condensate Separator and enters into the $4^{\text {th }}$ methanator. The effluent gas from the $4^{\text {th }}$ methanator is cooled in the $2^{\text {nd }} B F W$ Pre-heater and the process gas continually enters into the $5^{\text {th }}$ methanator.

\section{Results and Discussion}

The optimization of energy parameters such as the temperature and flow rate of the fluid in the heat exchanger in the gasification system based on several reasons as follows. The temperature and pressure of the high pressure superheated steam supply to the steam turbine are $490^{\circ} \mathrm{C}$ and 70 bar, respectively. The heat transfer process at the heat exchanger should be ensured that the temperature of the process gas after the $5^{\text {th }}$ Methanator is $280^{\circ} \mathrm{C}$.

Fig. 2(a) shows the effect of the inlet mass flow rate of the high pressure boiler feed water on the inlet energy of its $\mathrm{H}_{\mathrm{iHPBFW}}$, and the outlet energy of the high pressure superheated steam to turbine $\mathrm{H}_{\mathrm{oHPSST}}$, and the total inlet energy $\mathrm{H}_{\mathrm{i}}$ and total outlet energy $\mathrm{H}_{\mathrm{o}}$ of the heat exchangers of the gasification system. When the mass flow rate of the high pressure boiler feed water in the range of $123,134 \mathrm{~kg} / \mathrm{h}$ to $175,907 \mathrm{~kg} / \mathrm{h}$, the total outlet energy of the heat exchangers $\mathrm{H}_{\mathrm{o}}$ and the total outlet energy of the high pressure superheated steam to turbine $\mathrm{H}_{\mathrm{oHPSST}}$ increased quickly and then increased slowly. This is explained briefly as follows. In the range of mass flow rate from $123,134 \mathrm{~kg} / \mathrm{h}$ to 175,907 $\mathrm{kg} / \mathrm{h}$, the state of the work liquid in the steam drum is superheated vapor state and reduces gradually to saturated vapor state. Therefore, its enthalpy is also corresponding reduction. However, the increasing of the mass flow rate of the high pressure boiler feed water rather than the reducing of the enthalpy lead to the outlet energy $\mathrm{H}_{\text {oHPSST }}$ and $\mathrm{H}_{\mathrm{o}}$ are increase (see Fig. 2(a)). After the value of $175,907 \mathrm{~kg} / \mathrm{h}$, its state is reduced from saturated vapor state to saturated water-vapor mixture state but is close to saturated state. Therefore, its enthalpy is strongly decreased from the saturated vapor enthalpy to near the saturated water enthalpy. For this reason, the outlet energy $\mathrm{H}_{\mathrm{oHPSST}}$ and $\mathrm{H}_{\mathrm{o}}$ are slowly augmented.

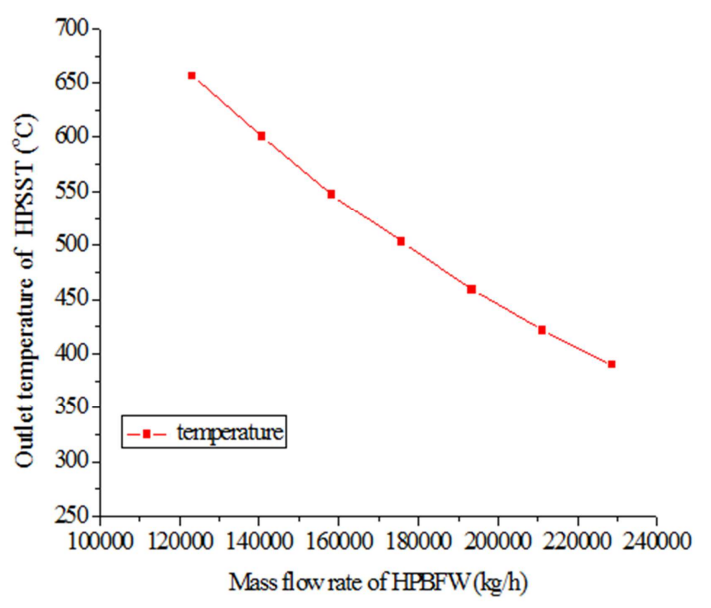

Fig. 3. Effect of the inlet mass flow rate of the high pressure boiler feed water on the outlet temperature of the high pressure superheated steam to turbine.

The effect of inlet mass flow rate of the high pressure boiler feed water on the total recovery energy of the heat exchangers $\delta H$ is shown as Fig. 2(b). As seen in Fig. 2(b), it demonstrates that increasing of the total recovery energy of the heat exchangers $\delta H$ is highest at $193,497.7 \mathrm{~kg} / \mathrm{h}$. Also, when the inlet mass flow rate of the high pressure boiler feed water is increased, it will lead to the outlet temperature of the high pressure superheated steam to turbine is reduced (see Fig. 3).

As indicated in Fig. 4(a), when the inlet temperature of the high pressure boiler feed water ranges from $77^{\circ} \mathrm{C}$ to $110^{\circ} \mathrm{C}$, the state of the work liquid in the steam drum is the saturated mixture state. At the value $110^{\circ} \mathrm{C}$, its state is saturated vapor state and then becomes superheated vapor state. The state change of the work liquid in the steam drum is the cause of the change of total outlet energy of the heat exchangers $\mathrm{H}_{\mathrm{o}}$ and total outlet energy of the high pressure superheated steam to turbine $\mathrm{H}_{\mathrm{OHPSST}}$ is shown in Fig. 4(a). Fig. 4(b) shows that the total recovery energy of the heat exchangers $\delta H$ is highest at $110^{\circ} \mathrm{C}$. As seen in Fig. 5, when the inlet temperature of the high pressure boiler feed water ranges from $77^{\circ} \mathrm{C}$ to $143^{\circ} \mathrm{C}$, the outlet temperature of the high pressure superheated steam to turbine increased from $476.2^{\circ} \mathrm{C}$ to $518^{\circ} \mathrm{C}$.

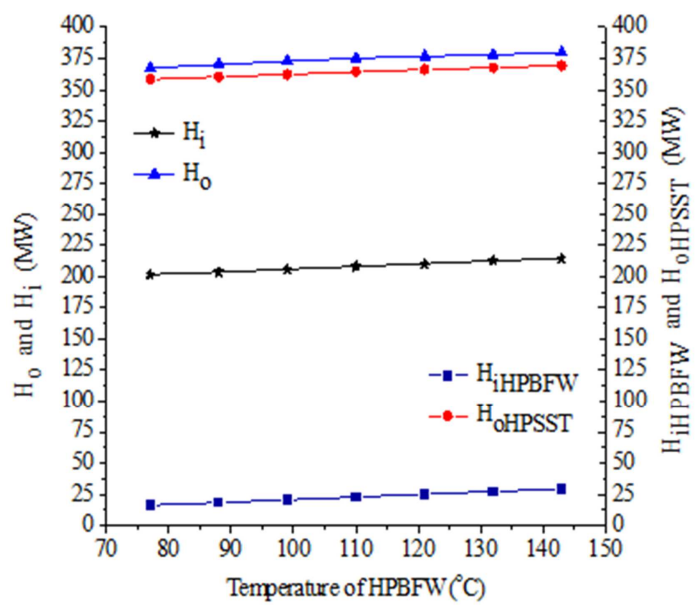

(a) Effect of the total inlet energy (Hi) 


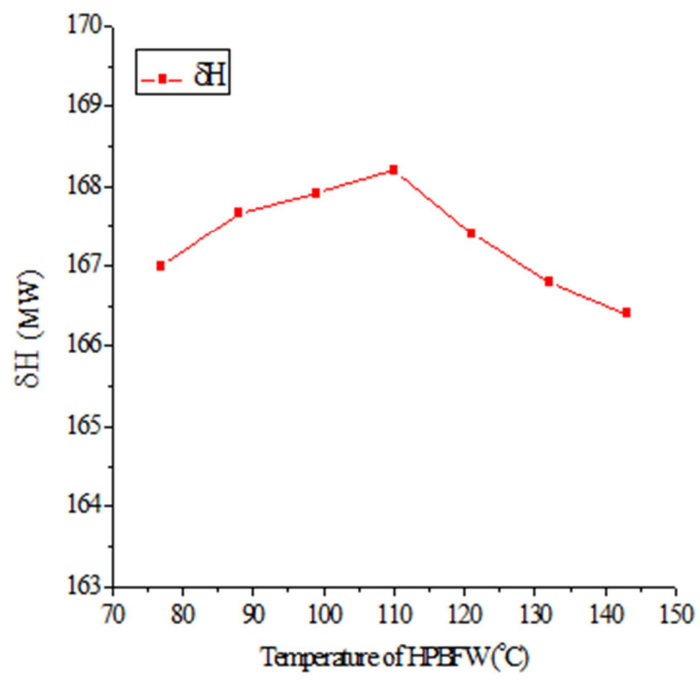

(b) Effect of the total recovery energy $\delta H$

Fig. 4. Effect of inlet temperature of the high pressure boiler feed water on the total inlet energy, the total outlet energy and the total recovery energy.

The total outlet energy $\left(\mathrm{H}_{\mathrm{o}}\right)$; The inlet energy of the HPBFW $\left(\mathrm{H}_{\mathrm{iHPBFw}}\right)$ and the outlet energy of the HPSST $\left(\mathrm{H}_{\mathrm{oHPSST}}\right)$

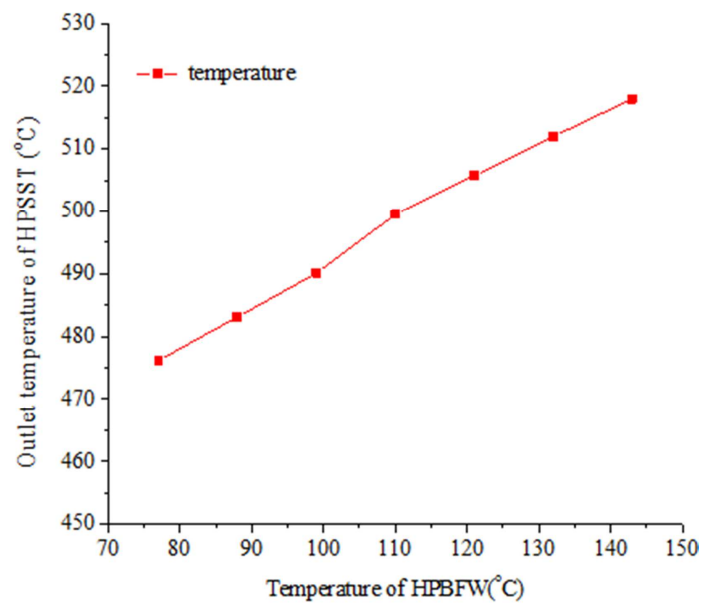

Fig. 5. Effect of inlet temperature of the high pressure boiler feed water on outlet temperature of the high pressure superheated steam to turbine.

Although the highest value of total recovery energy of the heat exchangers $\delta H$ obtained at $193,497.7 \mathrm{~kg} / \mathrm{h}$ (see Fig. 2(b)). However, at the value $193,497.7 \mathrm{~kg} / \mathrm{h}$, the outlet temperature of the high pressure superheated steam to turbine is $458^{\circ} \mathrm{C}$, this temperature does not meet the above requirement temperature. Furthermore, in the range of inlet mass flow rate of the high pressure boiler feed water from $175,907 \mathrm{~kg} / \mathrm{h}$ to $193,497.7 \mathrm{~kg} / \mathrm{h}$, the increasing of total recovery energy of the heat exchangers $\delta H$ is slightly. From the above analyses, the optimal mass flow rate and temperature of high pressure boiler feed water are determined at $175,907 \mathrm{~kg} / \mathrm{h}$ and $110^{\circ} \mathrm{C}$, respectively. At these values, the outlet temperature of high pressure superheated steam to turbine is $499.8^{\circ} \mathrm{C}$. In addition, these values also satisfy the above requirements.

To calculate for case of the high pressure saturated steam of the boiler, the parameters of the high pressure boiler feed water such as mass flow rate, temperature and pressure are kept constant at value of $175,907 \mathrm{~kg} / \mathrm{h}, 110^{\circ} \mathrm{C}$ and 100 bars, respectively. As seen in Fig. 6(a), when the inlet mass flow rate of the high pressure saturated steam of the boiler rises, the inlet energy of its $H_{i H P S T B}$ and the outlet energy of the high pressure superheated steam to turbine HoHPSST, and the total inlet energy $\mathrm{Hi}$ and total outlet energy Ho of the heat exchangers of the gasification system are increased. This increasing is due to the main increasing of inlet mass flow rate of the high pressure saturated steam of the boiler because of its saturated vapor enthalpy does not change state. For this reasons, the amount of the total recovery energy of the heat exchangers is almost unchanged (see Fig. 6(a)). However, the outlet temperature of the high pressure superheated steam to turbine is reduced when the inlet mass flow rate of the high pressure saturated steam of the boiler is increased (see Fig. 7). At the value of $238,430 \mathrm{~kg} / \mathrm{h}$, the outlet temperature of the high pressure superheated steam to turbine is $499.8^{\circ} \mathrm{C}$.

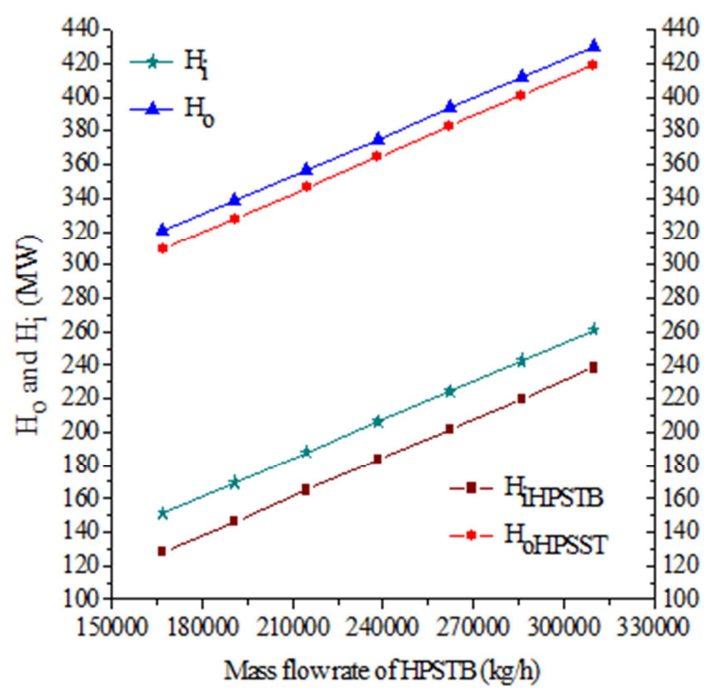

(a) Effect of the total inlet energy (Hi)

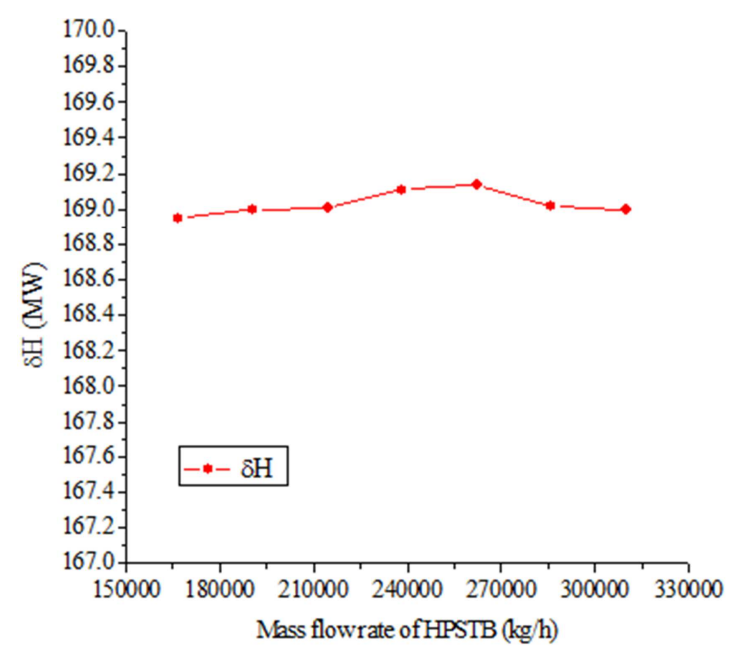

(b) Effect of the total recovery energy $\delta H$

Fig. 6. Effect of inlet mass flow rate of the high pressure saturated steam of the boiler on the total inlet energy, the total outlet energy and the total recovery energy.

The total outlet energy (Ho); The inlet energy of the HPBFW (HiHPBFW) and the outlet energy of the HPSST (HoHPSST) 


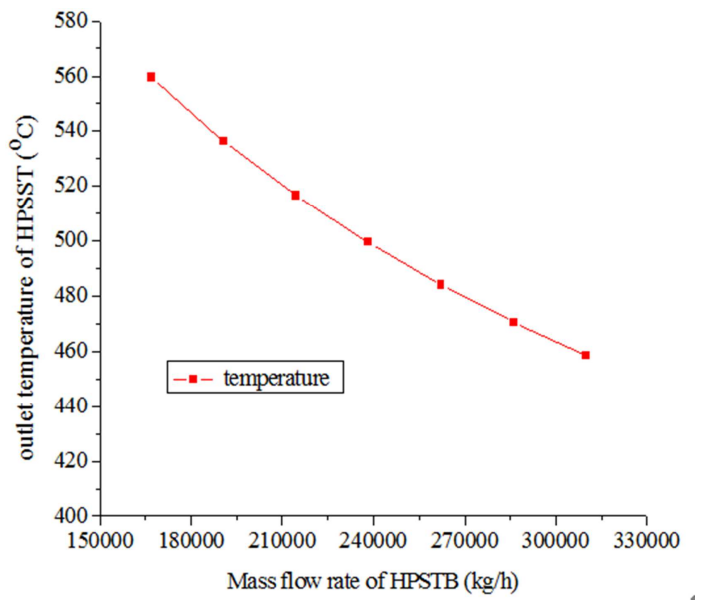

Fig. 7. Effect of inlet mass flow rate of the high pressure saturated steam of the boiler on outlet temperature of the high pressure superheated steam to turbine.

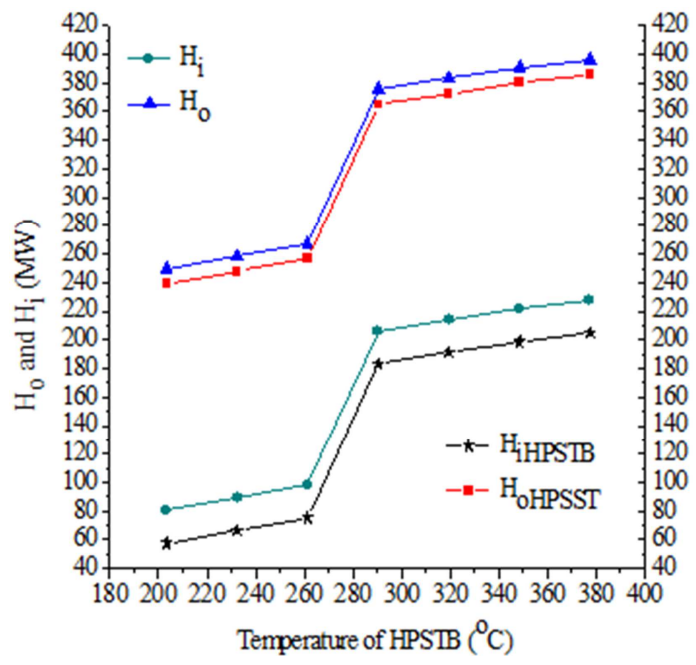

(a) Effect of the total inlet energy (Hi)

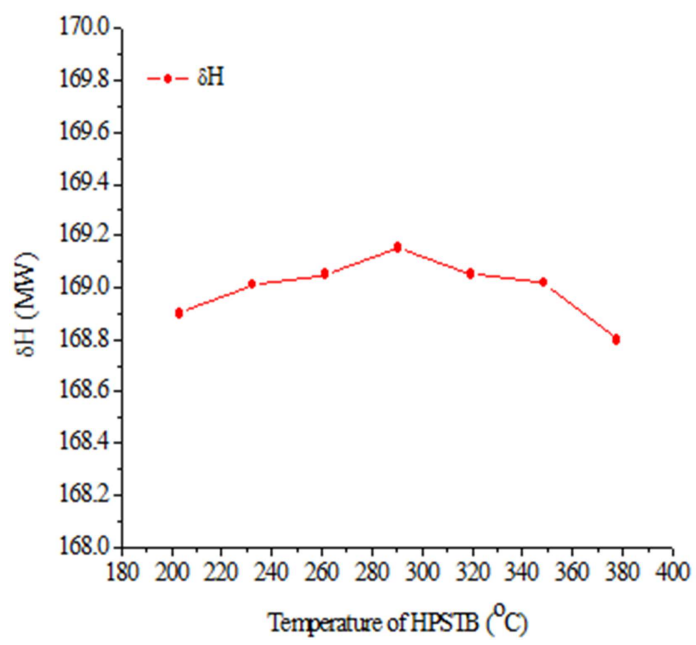

(b) Effect of the total recovery energy $\delta H$

Fig. 8. Effect of inlet temperature of the high pressure saturated steam of the boiler on the total inlet energy, the total outlet energy and the total recovery energy.

The total outlet energy $\left(\mathrm{H}_{\mathrm{o}}\right)$; The inlet energy of the HPBFW $\left(\mathrm{H}_{\mathrm{iHPBFw}}\right)$ and the outlet energy of the HPSST $\left(\mathrm{H}_{\text {oHPSST }}\right)$
Fig. 8 (a) shows the variations of the inlet energy of the high pressure saturated steam of the boiler $H_{i H P S T B}$, the outlet energy of the high pressure superheated steam to turbine $\mathrm{H}_{\text {oHPSST }}$, and the total inlet energy $\mathrm{H}_{\mathrm{i}}$ and total outlet energy $\mathrm{H}_{0}$ of the heat exchangers with respect to the inlet temperature of the high pressure saturated steam of the boiler. By increasing the inlet temperature of the high pressure saturated steam of the boiler until the value of $261.45^{\circ} \mathrm{C}$, the inlet energy of the high pressure saturated steam of the boiler $H_{\text {iHPSTB }}$, the outlet energy of the high pressure superheated steam to turbine $\mathrm{H}_{\mathrm{OHPSST}}$, and the total inlet energy $\mathrm{H}_{\mathrm{i}}$ and total outlet energy $\mathrm{H}_{0}$ of the heat exchangers increased slowly; however, from $261.45^{\circ} \mathrm{C}$ to $290.5^{\circ} \mathrm{C}$, they increase quickly and then increased slowly. This is because, in the range of temperatures from $203.35^{\circ} \mathrm{C}$ to $261.45^{\circ} \mathrm{C}$, the state of the high pressure saturated steam of the boiler is saturated liquid-vapor mixture state but close to saturated liquid state while at $290.5^{\circ} \mathrm{C}$ it is saturated vapor state and then becomes superheated vapor state. Therefore, enthalpy changes that correspond to the state of the high pressure saturated steam of the boiler lead to the highest total recovery energy of the heat exchangers $\delta H$ at $290.5^{\circ} \mathrm{C}$ (see Fig. 8 (b)). Fig. 9 shows the effect of inlet temperature of the high pressure saturated steam of the boiler on outlet temperature of the high pressure superheated steam to turbine. In the range of $203.35^{\circ} \mathrm{C}$ to $261.45^{\circ} \mathrm{C}$, the outlet temperature of the high pressure superheated steam to turbine is constant at $289^{\circ} \mathrm{C}$; however, from $261.45^{\circ} \mathrm{C}$ to $290.5^{\circ} \mathrm{C}$, it increase quickly and then increased slowly. As the above analysis shows, the optimal mass flow rate of high pressure saturated steam of the boiler is determined at $238,430 \mathrm{~kg} / \mathrm{h}$ while optimal temperature is $290.5^{\circ} \mathrm{C}$ and pressure is 74 bars.

In this study, the waste heat amount from air cooler is also investigated. The simulation results show that, when sixty percent of the heat release amount of the air cooler (12.78MW) is used, the total recovery energy of the heat exchangers $\delta H$ could be increased by $4.61 \%(7.8 \mathrm{MW})$.

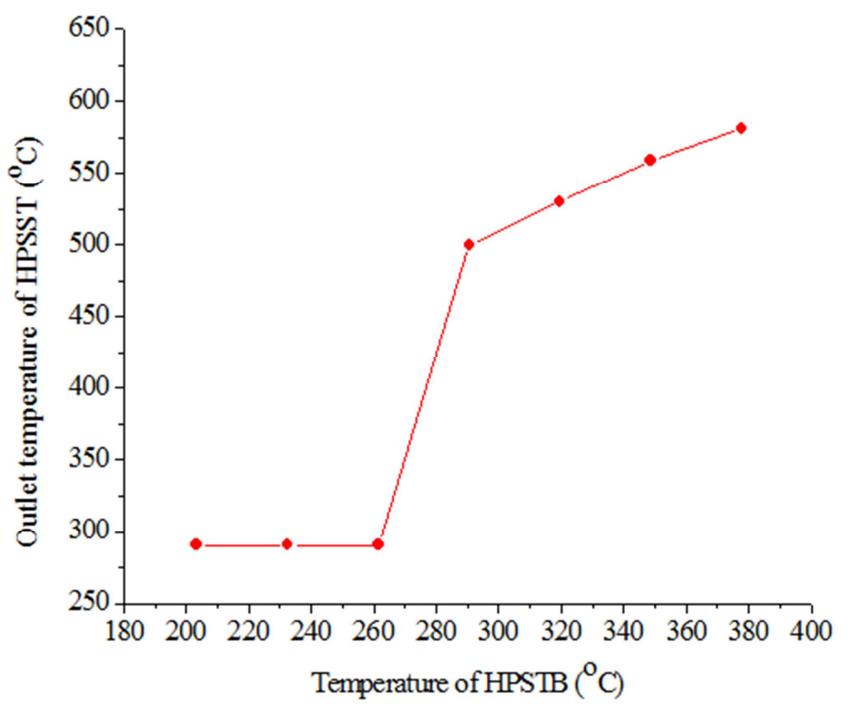

Fig. 9. Effect of inlet temperature of the high pressure saturated steam of the boiler on outlet temperature of the high pressure superheated steam to turbine. 


\section{Conclusions}

In this study, a mathematical model of a heat exchanger based on the effectiveness-NTU method is developed to predict its operating performance for the purpose of optimal temperature and mass flow rate of the fluid in the heat exchangers of the gasification system. Computational simulations have proved that the optimal mass flow rate, temperature and pressure of the high pressure boiler feed water are determined at $175,907 \mathrm{~kg} / \mathrm{h}, 110^{\circ} \mathrm{C}$ and 100 bars, respectively, while the optimal mass flow rate, temperature and pressure of the high pressure saturated steam of the boiler are determined at $238,430 \mathrm{~kg} / \mathrm{h}, 290.5^{\circ} \mathrm{C}$ and 74 bars, respectively. Moreover, the sixty percent of the heat release amount of the air cooler $(12.78 \mathrm{MW})$ is also proposed to use because the total recovery energy of the heat exchangers $\delta H$ could be increased by $4.61 \%(7.8 \mathrm{MW})$.

\section{Acknowledgements}

This work was supported by the Technology Innovation Program (No. 2011T100200036, Technology development for the demo-scale SNG synthesis) funded by the Ministry of Knowledge Economy (MKE, Republic of Korea)

\section{References}

[1] Kopyscinski J., Schildhauer T. J., Boillaz S. M. A., Production of synthetic natural gas (SNG) from coal and dry biomass - A technology review from 1950 to 2009, Fuel, Vol. 89, pp. 1763-1783, 2010

[2] Cronomarkovic N., Repic B., Neskovic O., Veljkovic M., Mladenovic R., Experimental investigation of role of steam in entrained flow coal gasification, Fuel, Vol. 86, pp. 194-202, 2007

[3] Bell D. A., Towler B. F., Fan M. H., Coal Gasification and its Applications, Oxford OX5 1GB, UK, 2011

[4] Luan Y. T., Chyou Y. P., Wang T., Numerical analysis of gasification performance via finite-rate model in a cross-type two-stage gasifier, International Journal of Heat and Mass Transfer, Vol. 57, pp. 558-566, 2013

[5] Jaojaruek K., Mathematical model to predict temperature profile and air-fuel equivalence ratio of a downdraft gasification process, Energy Conversion and Management, Vol. 83, pp. 223-231, 2014

[6] Materazzi \& et al., Thermodynamic modelling and evaluation of a two-stage thermal process for waste gasification, Fuel, Vol. 108, pp. 356-369, 2013

[7] Choi Y. C., Li X. Y., Park T. J., Kim J. H., Lee J. G., Numerical study on the coal gasification characteristics in an entrained flow coal gasifier, Fuel, Vol. 80, pp. 2193-2201, 2001

[8] Morris M., Waldheim L., Energy recovery from solid waste fuels using advanced gasification technology, Waste management, Vol. 18, pp. 557-564, 1998

[9] Stoecker W. F., Design of thermal system, 3th ed. McGraw-Hill Book, pp. 82-93, 1989
[10] Incropera F. P., Dewitt D. P., Bergman T. L., Lavine A. S., Fundamentals of Heat and Mass Transfer, 6th ed. John Wiley \& Sons Inc., 2006, pp. 669-723, 2006

[11] Hodge B. K., Analysis and Design of Energy system. Prentice-Hall, Inc., 1985

[12] Zedtwitz P. V., Steinfeld A., The solar thermal gasification of coal-energy conversion efficiency and $\mathrm{CO}_{2}$ mitigation potential, Energy, Vol. 28, pp. 441-456, 2003

[13] Ye D. P., Agnew J. B., Zhang D. K., Gasification of a South Australian low-rank coal with carbon dioxide and steam: kinetics and reactivity studies, Fuel, Vol. 77, pp. 1209-1219, 1998

[14] Chavan P. D., Sharma T., Mall B. K., Rajurkar B. D., Sharma B. K., Kulkarni B. D., Development of data-driven models for fluidized-bed coal gasification process, Fuel, Vol. 93, pp. 44-51, 2012

[15] Abani N., Ghoniem A. F., Large eddy simulation of coal gasification in an entrained flow gasifier, Fuel, Vol. 104, pp. 664-680, 2013

[16] Andrew J. M., Coal gasification for advanced power generation, Fuel, Vol. 84, pp. 2222- 2235, 2005

[17] Ahmed I., Gupta A. K., Evolution of syngas from cardboard gasification, Applied Energy, Vol. 86, pp. 1732-1740, 2009

[18] Kruse A., Hydrothermal biomass gasification, Journal of Supercritical Fluids, Vol. 47, pp. 391-399, 2009

[19] Erlach B., Harder B., Tsatsaronis G., Combined hydrothermal carbonization and gasification of biomass with carbon capture, Vol. 45, pp. 329-338, 2012

[20] Kakac S., Boilers, Evaporators, and Condensers, New York, John Wiley \& Sons Inc., pp. 11-67, 1991

\section{Biography}

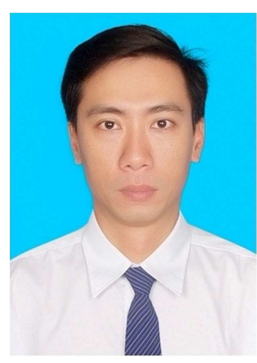

Le Minh Nhut received his B.S in Heat and Refrigeration Technology from Danang University of Technology in 2003 and M.S. degrees (in Thermal Engineering) from Vietnam National University, Ho Chi Minh City University of Technology in 2006, respectively. He then received his Ph.D degree from Jeju National University, Republic of Korea. He is currently a lecturer at the Ho Chi Minh City University of Technology and Education, Vietnam. His fields of interest include solar energy and application, refrigeration and air conditioning, and renewable energy.

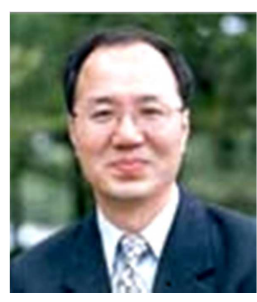

Youn Cheol Park received his B.E. in Mechanical Engineering, M.S., and Ph.D. degrees from Korea University in 1990, 1992 and 1997 respectively. He is now a Professor of the faculty of Mechanical Engineering, Jeju National University, Republic of Korea. His current research interests include Refrigeration, and Air conditioning. 